\title{
Political activism in Iran: strategies for survival, possibilities for resistance and authoritarianism
}

\author{
Paola Rivetti \\ School of Law and Government, Dublin City University, Dublin, Ireland
}

\begin{abstract}
This article examines mobilizations and activism in authoritarian settings by considering the case of Iran. By focusing on the transformation of activism since the 1990s and the green movement, it advances an explanation of how oppositional political groups have been able to survive and produce forms of resistant subjectivity despite authoritarian constraints. In order to do so, the article brings together two scholarly traditions, namely Social Movement Theory (SMT) and the study of subjectivity and resistance as framed by Sari Hanafi. SMT explains how activists have been able to navigate repression and create opportunities for mobilization while shifting between formal and informal politic. The study of subjectivity helps conceptualize the type of subjects or political citizens that authoritarian environments generate. The article builds on field research with activists conducted in Iran and Turkey between 2007 and 2016. It argues that authoritarian constraints allow autonomous activism to flourish while emptying of meaning the regime-sanctioned political infrastructures.
\end{abstract}

ARTICLE HISTORY Received 5 July 2016; Accepted 17 January 2017

KEYWORDS Iran; social movements; subjectivity; authoritarianism; mobilizations; protest movements; informal activism; green movement

In 2011, M. from Luxembourg was visiting a common friend in Eskisehir, a student town in Western Turkey. They are both Iranian but M. is a political refugee who resettled in Luxembourg after his application for asylum was accepted, while R. is AQ1 still waiting for her application to be processed by the UNHCR. I was invited to

1 dinner and the conversation quickly turned to common Iranian activist friends and life in post-green movement Iran. M. recalls that "shouting Allah-o-Akbar became a form of protest during the summer of 2009. It was a good form of protest, loud, meaningful, easy to diffuse. But it was dangerous because it is possible to recognize one's voice in the shouting. After the Ashoura protest, ${ }^{1}$ we all left the country. From here, we contacted our friends living in the student houses in Tehran to convince them not to remain silent [they were not shouting anymore for fear of being recognised] but to whistle: it is not possible to know who is whistling [but it] keeps the memory of the struggle alive." 2

This episode describes what activism looks like under authoritarian constraints, how it is protected, perpetuated and how it survives by relying on informal networks and 
personal friendship, on "weak" or "soft" forms of organization resulting from the need of adapting to changing circumstances, and on resilient defiance. This article tries to capture the working of these dynamics by asking how activism and activists survive in authoritarian settings, and what type of subjectivities are produced in such environments.

In the field of Middle Eastern studies, the scholarship postulates that "informal" activism is crucial to activists from the region because it often represents the only opportunity to organize. ${ }^{3}$ In fact, "formal" activism can easily be made illegal, as authorities can outlaw political personalities or parties arbitrarily. While acknowledging the relevance of informality, this article also finds that formal political organizations are crucial to the survival of activism in the case of Iran. In particular, it argues that it is the interplay between formality and informality that offers a better explanation of how oppositional activism survives authoritarian interventions. The $\mathrm{e} b \mathrm{~b}$ and flow of such an interplay does not happen in a vacuum, but is linked to variations in broader structural conditions. Iran has had successive waves of political opening and authoritarian strengthening since the end of the Iran-Iraq War in 1989, and underwent major popular mobilization in 2009 to 2010, thus constraining activists to opt for a diverse set of survival strategies. Such survival strategies, among which is the crossing of the "border" between formality and informality, while not a new phenomenon, ${ }^{4}$ suggest that activists express political agency while enacting them. These political citizens, able to circumnavigate authoritarian restrictions, are characterized by a sense of self-confidence and autonomy vis-à-vis both the political elite and regime-sanctioned political infrastructures, such as tolerated political parties and organizations.

Empirical evidence for this article is drawn from primary research conducted in Iran and Turkey between 2007 and 2016, including interviews (some of them repeated) with activists, observant participation in their activities, and personal fieldwork notes. Research in Turkey was conducted between 2009 and 2014, as it was not possible to travel to Iran and meet activists at the time, while research in Iran was conducted in 2007, 2008 and 2016, mainly in the capital Tehran. ${ }^{5}$ Here, I witnessed the environment that made the green movement possible and the legacy of it seven years later.

From a methodological point of view, a range of political formal and informal organizations were selected with the goal of reaching as many diverse activists as possible. Most of the political groups belong to the reformist camp and are supportive of a liberal democratic-oriented reform of the Islamic Republic. However, they are far from being homogeneous, as distinct visions of what a "reform" entails exist. More specifically, activists from the three most important reformist political parties (Mosharekat Front, E'temad-e Melli and Mojaheddin-e Enqelab) were interviewed, along with people from non-governmental organizations (NGOs) and loosely organized activist networks. The official position of political parties is one of advocating a gradual and moderate reform of the Islamic Republic, while activists from grassroots networks usually have more intransigent opinions about the need for a change. Generally, activists, even members of political parties, expressed frustration at the reformist elite's political choices, which are considered inconsistent and unrealistic. ${ }^{6}$ There is significant variation indeed in the opinions encountered, as individuals might diverge from the political line of the organization/group they are part of.

Building on Asef Bayat's ${ }^{7}$ work, this article considers that informal political platforms include non-movements, "infra-political" activities, ${ }^{8}$ networks, forums, protest campaigns, and loose coalitions that bind activists or activist networks together. 
Formal organizations include parties, unions, NGOs, and social movement organizations (SMOs) that are organized in a way that the state can recognize and engage with. This means that a highly confrontational social movement organized around a legal NGO with a horizontal structure and diffused leadership is considered formal if authorities can identify and engage with one or more referent or leader of it.

Finally, it is important to reiterate that neither the cleavage between radical or moderate positions vis-à-vis the state, nor the distinction between formality and informality are fixed. As already mentioned, they may shift over time according to changing structural circumstances (that is, a political party may be outlawed or a student organization may radicalize, experience repression and go underground or vice versa).

\section{Authoritarian politics and activism in the Middle East and North Africa}

Since the so-called Arab Spring erupted, scholars researching activism and SMOs in the region have interrogated their analytical toolkit. The prominence of the paradigms of democratization on the one side, and authoritarian resilience on the other side was challenged as both, despite their ambitions, were unable to capture the extreme variation of forms of political participation and authoritarian containment since 2010. This article primarily builds on SMT to explain how movements are repressed yet survive underground. Second, it uses Sari Hanafi's work on the "new," post-Arab Spring subjectivity 9 to elaborate on the type of subjects or political citizens that authoritarian environments generate.

SMT is broad and extremely rich but it has traditionally paid little attention to the Middle East and North Africa (MENA). Since the late 1990s though, the amount of research focusing on the MENA has increased and the uprisings and revolutions of 2010-2013 have further popularized academic interest in social movements in the region. This has inaugurated a critical dialogue between the scholars of the Middle East and classical SMT, with the result of not only enlarging the geographical scope of SMT but also exposing its weaknesses. ${ }^{10}$ This article specifically refers to two aspects that the study of MENA's social movements highlighted, contributing to the renovation of SMT: the analysis of social and political actors' agency in authoritarian contexts, and the study of informal activism.

First of all, the study of social movements in the MENA strengthened evidence that dissent and mobilizations may take place despite authoritarian conditions, although mainstream SMT theorists, as Arturo Escobar noticed in $1992,{ }^{11}$ have postulated the non-existence of social movements unless certain conditions, such as economic development, "levels of historicity" or democracy, were present. Escobar's remarks echoed Göran Therborn's invalidation of the thesis according to which social movements are present in democracies only. Therborn questioned the "zero-sum relation between the power of the state and the organization of political activities in general [...] when the state is strong, the opposition to it [...] is weak or non-existent; and when the state is weak the opposition [is] strong". ${ }^{12}$ As Bayat noticed, "Therborn has satisfactorily argued that such a conclusion is unjustifiable."

Beyond reinforcing the case for the study of protest movements in authoritarian settings, the deployment of SMT for the study of social movements in the MENA also fed into another important debate. Scholars of SMT in fact have voiced growing criticism of the excessive structuralism characterizing the political opportunity structure (POS), used to analyse the formation and development of contentious movements. POS is a 
set of specific conditions for mobilization available to activists at any given time. Dough McAdam identified three dimensions of it: access to a political system, intra-elite competition/conflict facilitating collective action, and decline in the state's repressive capability. Markoff added a fourth element, namely international pressure conducive to democratization or authoritarian strengthening. ${ }^{14}$ Criticism of POS not only revolved around the observation that such conditions were hardly present in efficient authoritarian systems but, above all, as Goodwin and Jasper wrote, that opportunities for mobilization "do not result from some invariant menu of factors, but from situationally specific combinations and sequences of political processes - none of which, in the abstract, has determinate consequences" 15

It is important to note that scholars critical of POS do not argue that structural conditions do not exist or are irrelevant. They rather take issue with the rigidity of the preselected "menu of conditions" POS contemplates as well as with the set of pre-determined scenarios that POS conditions should generate. As Jack Goldstone wrote,

we should note that POS has three major difficulties. (1) In pointing us to the "political," it emphasizes conditions relating to states, tending to neglect the role of counter-movements, allied movements, critical economic conditions, global trends and conjunctures, and various publics. (2) In pointing to "opportunity", as the label for changes releyant to movement actions, it tends to neglect how, in many cases, adversity - such as threats, excessive repression, or counter-movement actions - can energize and elevate movements, increasing their support and chances of success. (3) In pointing to "structures" (whether constant or changing) it tends to emphasize pervasive large-scale conditions, and suggest necessary and sufficient conditions for certain outcomes. ${ }_{i}^{16}$

Goldstone is in line with McAdam, Tarrow, and Tilly who, in their Dynamics of Contention, focused on the agency of actors involved in political contention. In particular, they emphasized the role of actors' changing perception of opportunity and threats, their active appropriation of venues and sites for contention against all odds, the dynamic framing of contention, the shifting repertoires of action and unstable alliance-building initiatives, in order to construct an explanatory model for mobilizations that places "relations" and "interpersonal networks" at its core. ${ }^{17}$

The attention that mainstream SMT has given to actors' agency and ability to deal with adverse conditions was not really new for scholars of the Middle East. In particular, Charles Kurzman's work had already advanced a social constructionist approach focused on the emotions, perceptions and meanings of actors engaged in contention to examine mobilizations. ${ }^{18} \mathrm{He}$ argued that these factors are crucial in creating a space for dissent, which did not necessarily exist before, in highly authoritarian situations. It follows that, although political limitations and constraints are present and especially so in authoritarian countries, activists may create opportunities for mobilization even when these are not evident. While structural conditions exist and come along with given opportunities for mobilization, they do not deterministically tell us how, when and why protests occur. In other words, actors' agency cannot be solely understood as resulting from given structural conditions. Echoing this approach, Pearlman recently proposed a micro-foundational analysis focusing on contrasting emotions such as anger, joy, pride or shame, sadness and fear to explain why individuals decide to join a protest, engendering broader movements. ${ }^{19}$

In line with Goldstone's third remark on POS' weaknesses, Joel Beinin and Frédéric Vairel $^{20}$ highlighted another critical aspect of MENA social movements, namely the predominance of scattered and fragmented, yet resilient, protest movements over 
cross-class, socially broad mobilizations. The two authors acknowledge that revolutions took place in the region (Iran in 1979, for example), but what they aim to highlight is that protest movements have generally taken a fragmented form as an effect of authoritarian constraints and a securitized approach to oppositional activities. ${ }^{21}$ As Pascal Menoret and Marie Duboc explain, ${ }^{22}$ authoritarian conditions may create the need for activists to conceal their activities when political engagément becomes too dangerous. Informality, along with fragmentation, then becomes crucial because it allows activists to disengage and re-orient their activities when their safety is at risk. This is an important function of informal activism, as activists may need to disappear or renegotiate their commitment.

It follows that the notion of informal activism, whose definition is currently debated, is core to the study of social movements in the MENA. The study of mobilizations during the so-called Arab Spring has shown how activists' later-to-be revolutionaries have been organizing in alternative, informal political platforms to escape the "tokenism" of the legal opposition, making an important contribution to the analysis of how activism and radical critique to the status quo survive and persist in authoritarian countries. ${ }^{23}$ Ellen Lust identified in activism "below the radar," based on personal networks, the most diffused form of organizing during the Arab uprisings and earlier. ${ }^{24}$ Maha Abdelrahman considers informal activism to happen in "decentralized, loose organizational structures," rejecting traditional leadership, relying on members to initiate activities, refusing the "capture the state" mantra, namely to take over institutions and assume power, and with a fluid membership that overlaps with other organizations. ${ }^{25}$ Lina Khatib and Ellen Lust define informal activism as happening in "less formal, loosely established" organizations, and refer to Bayat's notion of "non-movements" to indicate the "support networks" composed of individuals that "eventually formed an activist infrastructure that played a key role in the Arab Spring" ${ }^{26}$ Nouri Gana described Tunisian pre-2010 protests as "endogenous, private, non-organized activities" carried out by "everyday reyolutionaries (without a revolution) chipping away at the system [.. . W with a variety of individuated, stylized, and transversal actions and tactics that may or may not eventually become part of an overarching strategy of subversion" 27

While the relevance of grassroots informal activism during Iran's 2009-2010 and MENA's 2010-2013 uprisings was evident, this article argues that formal organizations too played a significant role. For example, the trade union Union General des Travailleurs Tunisien (UGTT) had a core role in the protests of 2010-2011. While its highranking officials were co-opted by Ben Ali's regime, low-rank members were not and were able to utilize a well-established organization for their revolutionary goals. A similar role was played by the Mosharekat Front and E'temad Party during the 2009-2010 mobilizations in Iran, ${ }^{28}$ as they offered a platform for mobilization to activists who were not necessarily enthusiastic about party politics. In fact, recognized political organizations such as parties or electoral committees may represent an opportunity for activists to mobilize when specific conditions occur. "Institutional" political platforms seem to become more appealing to activists when a partial political opening of the authoritarian system takes place due to election or international pressure. While the general trend of informalization of activism and growing mistrust towards "institutional" and recognized political organizations may not weaken, specific structural circumstances influence the activists' assessment as to how to survive authoritarian interventions and how to "utilize" the few opportunities for formal activism they 
have, propelling them to move between formality and informality and boosting their autonomous subjectivity.

\section{The informalization of activism}

Contrary to its granitic appearance, the Islamic Republic is a heterogeneous system both at the elite and popular level. At the elite level, fragmentation and factionalism within state institutions are promoted and protected as crucial aspects of the regime's resilience, $^{29}$ in contrast with the progressive centralization of power that characterized Ben Ali's Tunisia and Mubarak's Egypt. ${ }^{30}$ At the popular level, social movements too are rich in heterogeneity. In a sense, they mirror a decentralized elite system, which has historically allowed for limited pluralism.

Iranian activism, however, is not only shaped by the institutional structure it is merged in. The heterogeneity of revolutionary activism, rooted in the protest cycles that erupted in the late 1960s and led to the 1979 revolution, is the factor at the origin of the diversity of today's activism. Yet, following the establishment of the khomeinist hegemony in the early 1980s, the new regime "set the field" for acceptable activism, which aimed at strengthening the system now in place. Venues of political activism, such as university campuses, became a site of violent struggle between revolutionary groups, notably leftists and Islamists. The Cultural Revolution of the early 1980s put an end to the competition, forging a new type of university and student activism, while the Iran-Iraq War allowed for a state of exception that strengthened the regime's structure of authority. Until the end of the conflict in 1989, not only was the field of activism under strict control, with only a few organizations allowed to operate, but also the war and its legacy of heroes and martyrs reinforced narratives of national unity and homogeneity. ${ }^{31}$

Major socio-economic changes occurred at the end of the Iran-Iraq War, with a baby boom occurring and a relatively plural political atmosphere blooming again. Not only Jame'-e Ruhaniyat-e Mobarez, the only political organization in the country, split, giving birth to Majma'e Ruhaniyoun-e Mobarez and the distinction between the Islamic left and right, but also extant political groups were taken over by a new generation. Universities were the core of such transformations. Along with the Daftar-e Tahkim-e Vahdat (DTV), the only organization present on campuses until the late 1980s, other groups were established, such as Heshmatollah Tabarzadi's Daneshju-ye Bassij. $^{32}$ The number of university students, female especially, dramatically increased from 140,000 in 1977-1978 to $1,150,000$ in $1999 .{ }^{33}$ These new students came with new ideas about politics, and established organizations, such as the DTV, reflected this change. The DTV started attracting people with different views and opinions, losing early ideological centralism and eventually distancing itself from the regime. ${ }^{34}$ At the same time, prominent intellectuals, academics and politicians reassessed their previous values and positions, leading to profound and often critical reflections about the Islamic Republic. Abbas Abdi, Mohsen Kadivar, Abdolkarim Soroush, Hashem Aghajari, among the others, veered towards support for democratization and the introduction of genuine political pluralism. ${ }^{35}$

In the early 2000s, not only a dramatic number of NGOs was established with the support of the then reformist Khatami government, but also diverse frames for mobilization emerged in the discourse about activism. Beyond asking for a more democratic system and tolerance of pluralism, activists mobilized around ethnic diversity, or 
women's and prisoners' rights (new topics, as the war had flattened all diverse identities to reinforce national unity, and heavily securitized the public sphere). During my fieldwork on the campus of Tehran University in 2007-2008, I was able to appreciate the extreme variety of student groups. The DTV was organized into committees that enjoyed great autonomy and worked on specific issues, such as ethnic diversity or women's rights. Semi-legal leftist groups and these different DTV committees were a crucial asset the green movement later mobilized.

The green movement and the 2009-2010 uprising benefitted from the legacy of informal activist networks organized in groups or around campaigns on different issues, such as women, minorities and students' rights, ${ }^{36}$ who crucially joined Mousavi and Karoubi's electoral committees. Activists in fact rushed the campaign headquarters, as they saw in the election an opportunity to resurface after the conservative presidency of Ahmadinejad. This factor crucially facilitated mobilizations in 2009-2010. M.M. recalls that in 2008 independent student activists joined en masse the student branches of the Mosharekat Front and E'temad party to continue their activities, after their on-campus student associations were shut down. ${ }^{37}$ O., a student activist from Yazd, echoes M.M.'s words:
I became a university student in 2004 and entered the Jomhouri-khah association in Yazd. JK was unauthorized but tolerated on campus ${ }^{38}[\ldots]$ until 2005 when the university authorities closed down many organizations, among which was ours [...]. In 2004-2005 I was part of the electoral committee for Mostafa Mo'in [a presidential candidate, reformist] and I was active in campaigning for him. I had no office outside of his electoral committee, but I knew everybody [...]. In 2008, a bunch of people from the [local branch of] E'temad party contacted me and asked me to be part of his electoral committee in Yazd. So I became active in it and a party member, too. ${ }_{4}^{39}$

By taking over the electoral committees, activists also hoped to influence the contents of the candidates' programmes. Ma. for instance, who led and participated in a number of workers' actions at his own workplace without being part of any legal union, explains that he joined Mousavi's electoral committee Setad-e $88^{40}$ because he saw in it the opportunity to raise the issue of workers' rights more forcefully. ${ }^{41}$

By joining electoral committees, activists could also enlarge their networks and cooperate with like-minded people, marking a change from the oppressive atmosphere the government of the time created. J.J., a prominent woman activist, notes that this is something that has traditionally happened in Iran, well before the 2009 presidential election: "I was part of Khatami's electoral committee in 1996-1997 [...]. I established life-long friendships. After that I moved to social activism. [The electoral committee] however [...] was more about our own empowerment, it was very important to us to have the opportunity to experience empowerment." 42 Electoral committees represented a valuable asset for activists coming from loosely organized groups, as they offered opportunities to establish useful networks, alliances and relationships with peers and the elite.

However, the mobilization failed to consolidate a centre of power that could make inroads within institutional politics and avoid violent repression. The green movement expanded its composition and demands beyond the support for Mousavi and Karoubi, ${ }^{43}$ and was unable to "capture the state," substantiating its demands into policies. It remained dramatically exposed to repression. In such circumstances, "going underground" represented the only option for activists who wished to remain active. A.F., who was previously part of a legal political party and moved between the electoral 
committees of both Mousavi and Karoubi, describes this process, heavily based on personal connections:

I was the secretary of the student branch [of the Mosharekat Front in Shiraz] [...]. In 2009, I became a member of the Setad-e 88 [...] I did not want to work in a single headquarters, and then I worked for both Karoubi and Mousavi ...

Question: How could you be part of two committees?

Reply: well, we all knew each other and that was not a problem. After the election [...] I was active in some underground groups in Shiraz [...] that had no name [...]. We [...] knew each other and shared the same ideas. [...] We organized some demonstrations, and some sit-in [tahasson]. ${ }^{44}$

A journalist-activist, A., argued that "the colour green does not represent a unitary social order [...] it is a theoretical dispersion that lasted for a limited time [...] so I am not sure the green movement was very important" 45 This excerpt does not only reflect the rhizomatic and open-ended nature of the movement, but also the persisting disillusion that has remained with activists after the electoral "opening up" moment passed. $^{46}$

This discussion of Iranian activism suggests that three trajectories can be identified, which emphasize the intersection between structure, the activists' perception of threats/ opportunities, and their creative ability to seize/create opportunities for mobilization. The first trajectory is the diversification of activism, with the mushrooming of new groups, distinctive mentalities and ideological orientations. This occurred because of structural changes (end of the war, demographic changes, new generation in the labour market and education system, changes in institutional politics) and the activists' perception of lower costs of mobilization.

The second trajectory is the informalization of activism and subsequent individualization. Diversification caused the diffusion of critical views on the extant political infrastructures the regime provided. This increased the regime's inclination towards repression and securitization, propelling the younger generation to rely on informal networks, leading to a more fragmented, individualized type of activism. However, the informalization of activism did not exclude individual participation in recognized and structured organizations, such as electoral committees or political parties, under specific conditions such as election periods or structural "opening up".

The last trajectory is the weakening of the infrastructures of activism but at the same time the strengthening of activists' self-confidence and resilience. While informal networks are easier to disband, they also are less visible and have a greater chance of surviving than structured organizations, which can be outlawed with little effort. Informal activism therefore provides activists with room to manoeuver, go underground, engage or disengage from campaigns and groups, increasing their resilience and potential survival from repression. This has the effect of boosting their subjectivity, increasing selfconfidence and sense of autonomy from the political elite.

\section{Strategies for survival}

In addition to moving between formality and informality, another strategy for survival that activists adopt is to assess what "safe venues" for activism and "safe activities/ topics" may be. M. for instance reflects upon the limitations to activism and tells 
how he and his group (composed of like-minded friends he met on campus) decided to activate within universities. ${ }^{47}$ In fact, students' political activities are generally more legitimate as they enjoy a higher moral status thanks to the contribution they gave to the revolution:

It is not possible for example that socialists, democrats, social-democrats, liberals or secular leftists or rightists operate as a party. [...] all must operate within the limits of the Islamic Republic. We accepted this condition [...]. We focused our activities within universities because the only voice that could express the political demands of the people, as shown by the history of the Islamic Republic, is that of student groups. The intellectuals were often repressed and eventually students were too, but students' voice is usually more tolerated. ${ }^{48}$

Likewise, religious celebrations and elections are a comparatively safer way to mobilize and seize opportunities for activism. M. states: "On the day of Ashoura you can take advantage of the situation to express some ideas [...] like the melli mazhabi ${ }^{49}$ did: they also took advantage of religious celebrations to express democratic ideas. We tried to talk to people and to make them understand that the Islamic Republic [...] should not be supported." ${ }^{\text {Do }}$ A.R., a student activist, reflects on how during election times things seem to "open up". While criticizing political parties as hierarchical and non-democratic, he was part of Mousavi's electoral committee in Urmieh, and reports how the election propelled the organization to be more democratic internally. He says: "I met Mousavi in person, I could speak to him. Our job was not to execute orders coming from above [...] during elections and campaigns, because they want to appear more democratic, everything is [internally] managed in a more democratic way." ${ }^{, 1}$

Assessment of the level of safety does not only focus on the "venues of activism" but on topics too, as M. tells:

During Khatami's presidency, the year 2000 was declared the international year of the dialogue among civilizations. So I established centres [kanoon] within the university named after the dialogue among civilisations, and in these centres students gathered, organized events, worked to promote cultural change [as well as] activities against the dictatorship. But after a while the imam-e jom'e (Friday preacher) of the university took a stand against these centres and they were closed down. ${ }^{5}$

The perception of threats is crucial to guide the activists' choices as to how to convert and redirect their activism. For instance, engaging in several campaigns is a strategy to confuse authorities. M. reports that on university campuses, where student groups are closely monitored, a possible option is diversifying activism and keeping the campaigns distinguished:

you must be active in various sectors, namely cultural, political, social, environmental, human rights, workers' rights, women's rights, etc. We separated these campaigns so they [university authorities] couldn't see that it was the same student activists who were now working [...] as environmental activists. ${ }^{53}$

The shift between in/formality and security assessments are core to the survival of activism, and so is coalition-building. The scholarship on the Arab uprisings emphasizes that coalition-building was crucial in bridging the scattered protests and mobilizations that had been occurring in Tunisia, Egypt and Morocco for a decade before the upheavals. ${ }^{54}$ Cause-oriented activism had a central role in bringing activists together, allowing them to network and collaborate. This built a common background that gave origin to 
the cross-class and cross-ideological "collaborative revolutionism" ${ }^{55}$ which proved critical to organize and sustain mobilizations after 2010.

In Iran, the political convergence of groups and activists' networks is still weak. As the activists highlight, authoritarian interventions are crucial to determine coalitionbuilding capacity, both in a positive and negative way. On the one side, authoritarian conditions urge activists to unite to resist political pressure:

[Hambastegi-e bozorg] ${ }^{56}$ you can't say it's a party, [...] we are forced [to join forces], not that we like it, because everyone would like to bring their ideas forward [...] But since there is no freedom of expression and no social and political freedoms, then let's be partners in a front like Hambastegi. ${ }^{57}$

However, on the other side, authoritarian conditions undermine attempts at cooperating. R.G. says that "we cannot work together [also because] efforts towards unity are closely monitored by the Islamic Republic", which nullifies them infiltrating activists' groups or arresting activists. ${ }^{58}$ A. too discusses the difficulty of coalition-building and laments the state of under-development of the Iranian opposition. While not seeing extreme ideological variation as a problem, A. thinks that the lack of opportunities for networking keeps the opposition from developing strength and skills. He compares this situation to a room that has never been aired:

the microbes grow indoors and in dirt. When a room is aired, they cannot grow. [...] For example [I said] we could have hundreds of different parties in Iran, but I think these wouldn't last more than five years [if the political system opened up] because they will no longer have anything to say [...] [the disunity of the opposition] is caused by the political system being locked up, there are no occasion for networking seriously and for a period of time. $^{59}$

Nevertheless, cases of collaboration exist. The above-mentioned informal coalition Hambastegi-e bozorg is an example. Despite being weak and not active in promoting political initiatives or mobilizations, it is still in place and its main function is to keep groups from both within and outside of Iran connected, offering a platform to discuss and network. Other forms and venues for cooperation exist. Specifically, political collaboration has occurred within electoral committees, as they represent an opportunity for activists to build connections. Cooperation among activists has also taken place thanks to the appearance in the mid-2000s of single-issue campaigns as a new repertoire of action.

In fact, along with the pluralization of the structures and venues of political activism, the repertoire of actions also changed. In the mid-2000s single-issue campaigns entered the field of activism along with more traditional forms of mobilization. An important example is the One Million Signatures Campaign (OMSC), established in 2006, which tried to change Iranian legislation in favour of women's rights and which represented a major innovation in Iranian activism. It has been successful in involving a growing number of women and men with contrasting ideological orientations, minimizing their conflicts. The OMSC was able to do so because it was built around a single issue, namely legislative initiatives in favour of gender equality. ${ }^{60}$ It served as a blueprint for other campaigns, such as the recent "Change the Male-Dominated Face of the Parliament", 61 which took off on the occasion of the 2016 parliamentary election. Campaigns have proven crucial to the survival of activism under authoritarian constraints, and it is no coincidence that they appeared during the rise to power of the conservatives in government, parliament, local politics and the broader state apparatus. 
Part of their success is also linked to the advent and spreading of social media. A., who began her activism in the group Meydan-e Zanan in 2006 and is currently engaged in the campaign "Open Stadiums", 62 tells that "campaigns protect the activists' identity better than [participating in] a march, where you might get shot. I run the campaign from my smartphone and I am very sensitive to online security. I have several accounts and no one is connected to my identity. It is [still] risky but less than organizing a sit-in. Several people are involved [...] this makes me feel safe somehow." ${ }^{63}$ In fact, campaigns have the advantage of "diffusing" political responsibility, an element that is crucial to activists operating under authoritarian constraints. In addition, managing a campaign is much easier than running an organization and campaigners can be located abroad and in Iran. However, contrary to what happened in the Arab world in 2010-2011, divisions within the opposition remain prevalent.

\section{Political subjects and resistance}

After explaining the activists' strategies for survival, the article engages the broader repercussions of political engagement in authoritarian environments in terms of subjectivity. What kind of political individuals do authoritarian conditions produce? In his work on subjectivity after the Arab uprisings, Sari Hanafi argues that the revolutions in North Africa have produced "new subjectivities" that have "reflexive individualism" at their core. By this term, Hanafi means that new subjectivities reflect the fragmentation of previous social and economic systems, leaving room for a more individualized, autonomous subjectivity to emerge. However, Hanafi argues, this is not a neo-liberal, competitive, anti-social subject, but "it is a type of individualism that involves the constant negotiation [...] with the existing social structure in order to realize a (partial) emancipation from it. This is an act of self-reference of an agent that recognizes forces of socialization but alters their place in the social structure and resists their disciplinary power." ${ }^{64}$ Hanafi's approach resonates with Negri and Hardt's ${ }^{65}$ argument that subjectivities can create a space free from the disciplinary forces of the state and the market, helping us understand the long-term implications of activism in Iran and authoritarian settings.

In Iran, as discussed, the changes that have occurred since the end of the Iran-Iraq War and more recently the 2009-2010 mobilizations have distanced the activists from regime-provided political infrastructures, or what Hanafi called "the existing structures", strengthening their autonomy. Activists' independence has also been reinforced by the interplay between formality and informality. In fact, while activists seize all opportunities for mobilization that the state may offer, as discussed about their en masse participation in electoral committees and party branches in 2008-2009, disillusion with and autonomy from "institutional" politics still prevailed among activists after the "electoral moment". In fact, they voice a sense of emancipation from institutional politics and a growing awareness of their own agency. This resonates with Hanafi's notion that subjectivities are at the same time shaped by the environment they are merged in, but also "pushed away" towards autonomy. In his words, "agent [s] that [recognize] forces of socialization but [alter] their place in the social structure and [resist] disciplinary power" 66

AB., who was part of Tehran's Setad-e 88, advances a strong view about his role in the 2009-2010 mobilizations and voices a bold self-confidence. The perception of the importance of his role in the mobilizations originates from informal activism and 
networking. A sense of autonomy from both regime-sanctioned political platforms and the green movement's elite permeates AB.'s words:

[My role was to] text people spreading news, because websites were blocked, newspapers closed down and satellite antennas were out of order. [Recipients of my texts were] about 5,000 [...] [circulating updates] was done [also] by e-mail, or CDRom [...] There was a sort of army fighting against the regime. This army had generals, for example Mousavi, Karoubi, the Mosharekat Front and others. Then, you had officers [afsaran], it was us. And then soldiers who were the people, ordinary people. Two months after the election, the generals were jailed or arrested but the army was still at war. So, they [the security forces and conservatives in power] realized that the army, even with no generals, was working and that the struggle was ongoing. [...] They realized afsaran were even more important than generals, because afsaran had the contacts with the people who took to the streets. Some of us [afsaran] were already in politics, we had social capital we could build on ... we were intellectually independent ... we were in such a position that we could lead the movement and make decisions when the generals were jailed and not accessible anymore.

Question: What was your relation with the generals?

Reply: we had two types of contact. One was direct contacts [...] I was in touch [...] Another way was that $[\ldots]$ we read newspapers and we were able to analyse and comment on the events and make decisions. So even when the generals were arrested, we were able to lead the people in their place. One of the things they asked me during interrogations [in Iran] was who called you to know where to go to take part in the demonstrations, what to do and what to bring. ${ }^{67}$

$\mathrm{AB}$. brings further evidence that grassroots activism led the protest movement when the repression was underway, and Karoubi and Mousavi were arrested. In fact, his testimony confirms the primacy of informal activism when the opportunities for mobilization that resulted from the electoral contention faded away, and the "opening up" moment passed. This strengthened the autonomy of grassroots activists from the elite, as they had to act independently and make decisions for themselves. AB.'s self-perception emerges from informal activism, in contrast to the elite of the green movement or "the generals". AB. expresses a strong agency in subverting the hierarchy of the army he talks about.

M. echoes AB.'s position. M., who describes himself as a "free spirit" although he entered the Setad-e 88 in 2009, discusses how informal structures take shape thanks to the experience of activists, independently from the political elite:

you see, there is a system that we Iranians know well. In fact this system is typical of countries that have long been under the sway of dictatorship; that is, when there is an opportunity no one loses time or leaves room for doubt and uncertainty and then just one says "come on!" they all throw themselves and follow him! We all, young, old, rightists, leftists, were fed up with the situation, then you don't need a modern organization with various hierarchies. A structure had already formed, in a traditional manner and over a long time. We had learned this from the experience of the university period [that people organize efficiently]. [...] This type of unity was born in the heart of our society, because the people, even those who had no direct access to the media or were not in contact with university, intellectuals and activists, had touched the problems and hardships of society and recognized the government as the one responsible. Then when an opportunity occurred, the people were determined and tried to change things. ${ }_{1}^{68}$

Both $\mathrm{AB}$. and $\mathrm{M}$. reclaim a fundamental role in making mobilizations possible and successful. They both reclaim the centrality of their agency, and seem to tell us that "we did it, we made it happen". Although this may be an exaggeration, what is relevant here is 
their self-perception and the type of independent subjectivity that they perceive as their own, especially after the repression of the protests and the arrest of Mousavi and Karoubi.

\section{Conclusion}

The article examined the strategies for survival that activists put in place when operating under authoritarian constraints, by focusing on the case of the Islamic Republic of Iran. In a longer trajectory of informalization of activism, loss of credibility of formal political organizations such as political parties, and of individualization of political engagement, the findings discussed here demonstrate that activists may opt for occupying spaces of formal institutional politics under specific conditions. These are periods of electoral campaigns, lowered securitization of public spaces and, more generally speaking, of increased opportunities for mobilization. This finding speaks to the relevance of activists' agency, who try to appropriate political space when given the opportunity. However, activists may need to shift between formality and informality as repression increases, enhancing their sense of independence and self-awareness. As their survival ability grows, activists become more aware of their own agency, voicing greater selfconfidence. This attitude has reinforced the sense of distance and mistrust towards "institutional" politics: currently, the efforts of President Rouhani to sell his government as the "government of moderation" (e'tedal) are met with scepticism among grassroots activists in Iran.

In conclusion, it seems that reinforced authoritarian constraints paradoxically help autonomous activism and subjectivity to flourish while emptying the regime-sanctioned political infrastructures of meaning. This is an unexpected outcome of authoritarian interventions, as the Iranian state spends significant resources in seeking and reproducing legitimacy through, for instance, elections and other civil celebrations.

\section{Notes}

1. In June 2009, protests erupted across Iran in reaction to the re-election of President Mahmoud Ahmadinejad, who won the electoral race against other candidates among whom were the reformists Mir Hossein Mousavi and Mehdi Karoubi. The protests lasted into the winter and came to be known as the green movement. One of the most violently repressed protests was held on the day of Ashoura (27 December 2009). Ashoura coincided with the death of Grand Ayatollah Montazeri, a prominent cleric critical of the regime and supportive of the protest movement, offering a further opportunity for mobilization.

2. Interview, male 36, November 2011, Eskişehir. The campaign was called soot-e èteraaz, sometimes also soot-e sabz (the protest whistle, the green whistle).

3. See Abdelrahman, Egypt's Long Revolution.

4. Holliday and Rivetti, "Divided we Stand?"; Menoret, "Leaving Islamic Activism Behind”; Duboc, "Egyptian Leftist Intellectuals' Activism."

5. In total, more than 60 in-depth interviews have been conducted. Fifteen have been used for this article.

6. Specifically, activists expressed disillusion with Mohammad Khatami, former president and reformist leader par excellence, but also with Mousavi, Karoubi and Hasan Rouhani. On the relationship between the reformist elites and activists, see Holliday and Rivetti, "Divided we Stand?"

7. Bayat, Life as Politics.

8. Scott, "Two Cheers for Anarchism," 20.

9. Hanafi, "The Arab Revolutions."

10. See for instance Della Porta, Mobilizing for Democracy. 
11. Escobar, "Imagining a Post-development Era?"

12. Bayat, "Capital Accumulation," 205. Bayat refers here to Therborn, "Why Some Classes Are More Successful than Others."

13. Ibid.

AQ2 14. McAdam, McCarthy, and Zald, Comparative Perspectives; Markoff, "Response to Jack Goldstone."

15. Goodwin and Jasper (1996), in Beinin and Vairel, Social Movements, 5.

16. Goldstone, "More Social Movements or Fewer?," 356.

17. McAdam, Tarrow, and Tilly, Dynamics of Contention.

18. Kurzman, "Structural Qpportunity."

19. Pearlman, "Emotions and the Microfoundations of the Arab Uprisings."

20. Beinin and Vairel, Social Movements.

21. Ibid. Despite presenting significant variations in the way they are organized and operate, authoritarian systems share common traits when it comes to their "greater autonomy from society [than democratic systems], though not necessarily from economic elites" and the exclusion of "certain mobilized groups from any role in political decision making" (Goodwin, No Other Way Out, 13).

22. Menoret, "Leaving Islamic Activism Behind"; Duboc, "Egyptian Leftist Intellectuals' Activism."

23. Khatib and Lust, Taking to the Streets; Abdelrahman, "In Praise of Organization"; Bayat, "The Arab Spring."

24. Abdelrahman, "In Praise of Organization”; Lust, "Why Now?"

25. Abdelrahman, Egypt's Long Revolution, 49.

26. Khatib and Lust, Taking to the Streets, 5.

27. Gana, The Making of the Tunisian Revolution, 2

28. Both reformist parties, they were made illegal in 2010. The first was supportive of Mir Hussein Mousavi while the second supported Mehdi Karoubi at the 2009 presidential election.

29. Keshavarzian, "Contestation without Democracy."

30. Hinnebusch, "Change and Continuity after the Arab Uprising."

31. Saeidi, "Creating the Islamic Republic."

32. Initially a pro-regime organization, later it moved towards a critical position face à the regime. Its leader, Heshmatollah Tabarzadi, has been in jail since December 2009. In the meantime, the organization has changed its name to Jebhe-ye democratik-e melli-e Iran and is also involved in extra-campus activities. It is part of the Hambastegi-ye bozorg coalition, which is a loose network of pro-democracy groups in Iran. The majority of its members, however, are today either jailed or abroad.

33. Mahdi, "The Student Movement," 11.

34. Rivetti, "Student Movements in the Islamic Republic."

35. Ghamari-Tabrizi, Islam and Dissent.

36. Adelkhah, "The Political Economy of the Green Movement"; Reisinezhad, "The Iranian Green Movement"; Pourmokhtari, "Understanding Iran's Green Movement."

37. Interview with M.M., a student activist in political science, previously member of the student branch of the Mosharekat Front, Tehran University (male, 27, August 2016, Tehran).

38. JK, a Yazd-based student group, was established on campus as an alternative to the local Islamic Association present on campus which, by the mid-2000s, fell into the hands of conservative students. JK is a non-affiliated democratic and liberal organization.

39. Personal interview, male, 30, April 2012, Nevşehir.

40. The name of Mousavi's electoral committee, which originally formed to support Khatami's candidacy. For an account of the activities of the committee, see Ghafouri, "Setad 88."

41. Interview, male, 35, April 2012, Niğde.

42. Interview, July 2016, Tehran. J.J. was a student activist when she was part of Khatami's campaign. After that, she joined a feminist NGO, Hastia Andish, before moving to the One Million Signatures Campaign and other smaller initiatives after that. She was jailed twice.

43. Hashemi, "Renegotiating Iran's Post-revolutionary Social Contract," 207.

44. Interview, male, 32, June 2013, Kayseri.

45. Interview, male, 27, December 2011, Niğde. A. collaborates with the online newspaper Rah-e sabz. 
46. A similar example is the involvement of grassroots student associations under the sponsorship of DTV in Khatami's electoral campaign in 1996 and in the Dovvom-e Khordad Front, an electoral coalition established for the 2000 parliamentary election. After multiple electoral successes, the repression of the 1999 student protests and other episodes of violence, disillusion spread among the students who distanced themselves from institutional politics and eventually took refuge in informal activism (Malekzadeh, "Education as a Public Good or Private Resource," 119). Currently, the DTV does not legally exist as the majority of the on-campus Islamic Associations that composed it are either closed or dominated by conservative students. However, prodemocracy students are in the process of reorganizing, with the goal of advancing students' demands. According to M.M., students' activism has dramatically changed. It left behind broad and political demands such as democratization or constitutional reform to focus on issues that are immediately relevant to the students, such as the privatization of higher education, increasing tuition fees and academic curricula (personal interview, male, 27, August 2016, Tehran).

47. He was born in 1980, so he entered university in 2000 .

48. Interview, male, 36, November 2011, Eskişehir.

49. Name to indicate the modernist, nationalist and moderately secular forces in Iran. Here, M. refers to them during the revolution.

50. Interview, male, 36, November 2011, Eskişehir.

51. Interview, male, 26, May 2013, Kayseri.

52. Interview, male, 36, November 2011, Eskişehir.

53. Ibid.

54. Khatib and Lust, Taking to the Streets; Chalcraft, Popular Politics; Clarke, "Saying 'Enough'."

55. "The collaborative work [that] emerges as [...] the by-product of the collective actions of noncollective actors," as defined by Gana (The Making of the Tunisian Revolution, 2).

56. Hambastegi is a coalition coordinating various pro-democracy political groups/individuals. It has been off and on. Currently, most of its members are either jailed or outside of Iran. The latest spokesperson was Heshmatollah Tabarzadi.

57. Interview with R.M., male, 37, April 2013, Eskişehir.

58. Interview, male, 31, November 2011, Eskişehir.

59. Interview, male, 27, December 2011, Niğde.

60. Bøe, Family Law in Contemporary Iran, 162-169.

61. See http://www.women4parliament.org/ (accessed 4 July 2016).

62. See https://twitter.com/openstadiums?lang=en (accessed 4 July 2016). "Open Stadiums" demands the end of the exclusion of women from stadiums and sport events. Meydan-e Zanan was a feminist independent group. It emerged from the campaign to stop stoning in 2006 organized by the feminist NGO Rahi Institute, led by Shadi Sadr and Mahboube Abbasgholizadeh.

63. Interview, female, 33, June 2016, Tehran.

64. Hanafi, "The Arab Revolutions," 203.

65. Hardt and Negri, Empire.

66. Hanafi, "The Arab Revolutions," 203.

67. Interview, male, 32, June 2012, Istanbul.

68. Interview, male, 36, April 2013, Eskişehir.

\section{Acknowledgement}

I am grateful to Francesco Cavatorta and Shirin Saeidi for their comments and critiques on the early drafts of this article. I presented this research at the annual conference of the British International Studies Association in 2016 and at the University of Manchester, Department of Arabic and Middle Eastern Studies, in 2017, and I thank those who engaged with me on those occasions.

\section{Disclosure statement}

AQ3 No potential conflict of interest was reported by the author. 


\section{Funding}

I am also grateful to the Irish Research Council [grant number ID REPRO/2015/33] for supporting my research.

\section{Notes on contributor}

Paola Rivetti is a lecturer in the Politics of the Middle East and International Relations at Dublin City University, Ireland.

\section{Bibliography}

Abdelrahman, Maha. "In Praise of Organization: Egypt between Activism and Revolution." Development and Change 44, no. 3 (2013): 569-585.

AQ4 Abdelrahman, Maha. Egypt's Long Revolution. London: Routledge, 2015.

- Adelkhah, Fariba. "The Political Economy of the Green Movement: Contestation and Political Mobilization in Iran." In Iran: From Theocracy to the Green Movement, edited by Negin Nabavi, 17-38. New York: Palgrave, 2012.

Bayat, Asef. "Capital Accumulation, Political Control and Labour Organization in Iran, 1965-75." Middle Eastern Studies 25, no. 2 (1989): 198-207.

Bayat, Asef. Life as Politics. How Ordinary People Change the Middle East. Stanford, CA: Stanford University Press, 2010.

Bayat, Asef. "The Arab Spring and its Surprises." Development and Change 44, no. 3 (2013): 587-601.

Beinin, Joel, and Fréderic Vairel, eds. Social Movements, Mobilization, and Contestation in the Middle East and North Africa. Stanford, CA: Stanford University Press, 2011.

Bøe, Marianne. Family Law in Contemporary Iran: Women's Rights Activism and Shari'a. London: IB Tauris, 2015.

Chalcraft, John. Popular Politics in the Making of the Modern Middle East. Cambridge: Cambridge University Press, 2016.

Clarke, Killian. “Saying 'Enough': Authoritarianism and Egypt's Kefaya Movement.” Mobilization 16, no. 4 (2011): 397-416.

Della Porta, Donatella. Mobilizing for Democracy. Comparing 1989 and 2011. Oxford: Oxford University Press, 2014.

Duboc, Marie. "Egyptian Leftist Intellectuals' Activism from the Margins. Overcoming the Mobilization/Demobilization Dichotomy." In Social Movements, Mobilization, and Contestation in the Middle East and North Africa, edited by J. Beinin and F. Vairel, 49-67. Stanford, CA: Stanford University Press, 2011.

Escobar, Arturo. "Imagining a Post-development Era? Critical thought, Development and Social AQ5 Movements." Social Text, no. 31/32 (1992): 20-56.

Gana, Nouri. The Making of the Tunisian Revolution: Contexts, Architects, Prospects. Edinburgh: Edinburgh University Press, 2013.

Ghafouri, Arash. "Setad 88 - Iran's Greatest Campaign in Support of Mir Hossein Mousavi." In Election Fallout. Iran's Exiled Journalists on Their Struggle for Democratic Change, edited by M. Michaelsen, 50-64. Berlin: Verlag Hans Schiller, 2009.

Goldstone, Jack. "More Social Movements or Fewer? Beyond Political Opportunity Structures to Relational Fields." Theory and Society 33 (2004): 333-365.

Goodwin, Jeff. No Qther Way Out. State and Revolutionary Movements 1945-1991. Cambridge: Cambridge University Press, 2001.

Ghamari-Tabrizi, Behrooz. Islam and Dissent in Postrevolutionary Iran. Abdolkarim Soroush, Religious Politics and Democratic Reform. London: IB Tauris, 2008.

Hanafi, Sari. "The Arab Revolutions; the Emergence of a New Political Subjectivity." Contemporary Arab Affairs 5, no. 2 (2012): 198-213.

Hardt, Michael, and Antonio Negri. Empire. Harvard, MA: Harvard University Press, 2001.

Hashemi, Nader. "Renegotiating Iran's Post-revolutionary Social Contract: The Green Movement and the Struggle for Democracy in the Islamic Republic." In Beyond the Arab Spring. The Evolving Ruling Bargain in the Middle East, edited by M. Kamrava, 191-222. Oxford: Oxford University Press, 2014. 
Hinnebusch, Raymond. "Change and Continuity after the Arab Uprising: The Consequences of State Formation in Arab North African States." British Journal of Middle Eastern Studies 42, no. 1 (2015): $12-30$.

Holliday, Shabnam, and Rivetti, Paola. "Divided we Stand? The Heterogeneous Political Identities of Iran's 2009-2010 Uprisings." In Political Identities and Popular Uprisings in the Middle East, edited by S. J. Holliday and P. Leech, 17-35. London: Rowman and Littlefield, 2016.

Keshavarzian, Arang. "Contestation without Democracy: Elite Fragmentation in Iran." In Authoritarianism in the Middle East: Regimes and Resistance, edited by M. Pripstein Posusney and M. Penner Angrist, 63-88. Boulder, CO: Lynne Publishers, 2005.

Khatib, Lina, and Ellen Lust, eds. Taking to the Streets: The Transformation of Arab Activism. Baltimore, MD: Johns Hopkins University Press, 2014.

Kurzman, Charles. "Structural Opportunity and Perceived Opportunity in Social-Movement Theory: The Iranian Revolution of 1979." American Sociological Review 61 (1996): 153-170.

Lust, Ellen, "Why Now? Micro Transitions and the Arab Uprisings." The Monkey Cage, 2011. Accessed July 3, 2016. http://themonkeycage.org/wp-content/uploads/2011/10/Ellen_Lust_final.pdf.

Mahdi, Ali Akbar. "The Student Movement in the Islamic Republic of Iran." Journal of Iranian Research and Analysis 15, no. 2 (1999): 5-32.

Malekzadeh, Shervin. "Education as a Public Good or Private Resource: Accommodation and Demobilization in Iran's University System." In Power and Change in Iran. Politics of Contention and Conciliation, edited by D. Brumberg and F. Farhi, 101-134. Bloomington: Indiana University Press, 2016.

McAdam, Doug, Joh McCarthy, and Mayer Zald. Comparative Perspectives on Social Movements: Political Opportunities, Mobilizing Structures and Cultural Framings. Cambridge: Cambridge University Press, 1996.

McAdam, Doug, Sidney Tarrow, and Charles Tilly. Dynamics of Contention. Cambridge: Cambridge University Press, 2001.

Menoret, Pascal. "Leaving Islamic Activism Behind. Ambiguous Disengagement in Saudi Arabia." In Social Movements, Mobilization, and Contestation in the Middle East and North Africa, edited by J. Beinin and F. Vairel, 68-85. Stanford, CA: Stanford University Press, 2011.

Mokhtari, Shadi. “This Government is Neither Islamic nor a Republic': Responses to the 2009 Postelection Crackdown." In Power and Change in Iran. Politics of Contention and Conciliation,

AQ6 edited by D. Brumberg and F. Farhi, 251-282. Bloomington: Indiana University Press, 2016.

1 Pearlman, Wendy. "Emotions and the Microfoundations of the Arab Uprisings." Perspectives on Politics 11 , no. 2 (2013): 387-409.

Pourmokhtari, Navid. "Understanding Iran's Green Movement as a 'Movement of Movements'." Sociology of Islam 2, no. 3-4 (2014): 144-177.

Reisinezhad, Arash. "The Iranian Green Movement: Fragmented Collective Action and Fragile Collective Identity." Iranian Studies 48, no. 2 (2015): 193-222.

Rivetti, Paola. "Student Movements in the Islamic Republic: Shaping Iran's Politics through the AQ7 Campus." Chaillot Papers no. 128 (2012): 81-100.

1 Saeidi, Shirin. "Creating the Islamic Republic of Iran: Wives and Daughters of Martyrs, and Acts of Citizenship." Citizenship Studies 14, no. 2 (2010): 113-126.

Scott, James. Two Cheers for Anarchism. Six Easy Pieces on Autonomy, Dignity, and Meaningful Work and Play. Princeton, NJ: Princeton University Press, $201 \hat{2}$.

Sedgwick, Mark. "Measuring Egyptian Regime Legitimacy." Middle East Critique 19, no. 3 (2010): 251AQ8 267.

1 Therborn, Göran. "Why Some Classes Are More Successful than Others." New Left Review, no. 138 (1983): 37-56. 